\title{
The Spectre of Montezuma: Hospitality and Haunting
}

\author{
Gideon Baker ${ }^{1}$
}

\begin{abstract}
By way of a retelling of the story of Montezuma's tragic end at the hands of his inhospitable guest, Cortés, this article recovers the spectral presence of wronged hosts in the history of international hospitality. While conditional hospitality, as Jacques Derrida shows, is stalked by the absent or wronged guest, unconditional hospitality is disturbed by the abused host. Derridean deconstruction allows for this counter-haunting, but the host-harming history of hospitality has nonetheless been neglected for two reasons which a genealogy of hospitality illuminates. First, because it is the hospitality narrative of the little people who, though risking more in offering hospitality, have been marginal in writing its history. Second, because the little people's narrative was overwritten by the Homeric account of hospitality-the unlimited welcome of heroes by their fellow elites. Offering more but risking less, this aristocratic hospitality narrative no longer portrayed hosting as precarious. What deconstruction and genealogy together show is that hospitality could never be anything other than precarious, lacking both conceptual stability and historical continuity. Thus the ethics of hospitality is always already a politics of hospitality.
\end{abstract}

\section{Introduction}

Approaching Tenochtitlan, Hernán Cortés’ men let out a collective gasp of amazement.

Rising magnificently out of lake Texcoco, Montezuma's city seemed to come from another world to the dirt-poor pueblos they had left behind them in Spain; and indeed it did - the 'New World', discovered by men like themselves only 27 years before. The conquistadors, wondering whether they are dreaming, cannot marvel long at 'things never heard of, seen or dreamed of before'. ${ }^{2}$ Down a wide causeway linking the city to the lake shore there must be a thousand men approaching, each dressed in rich clothes which make the troops suddenly aware of their own dishevelled appearance after months of hard campaigning. The

\footnotetext{
${ }^{1}$ Many thanks to Naomi Baker; Renée Jeffery (and other participants at the Griffith University workshop where I presented an earlier version of this paper); Julian Reid; Julia Rudolph; three anonymous referees and the editors for their helpful comments.

${ }^{2}$ Bernal Díaz de Castillo, The Conquest of New Spain, translated by J.M. Cohen (New York: Penguin, 1963 [c.1568]), 214.
} 
atmosphere is tense, but as the delegation draws closer it is apparent that it is not armed. With growing relief, the troops watch as, one by one, the principal men of Tenochtitlan prostrate themselves before Cortés, each placing a hand against the ground and kissing it. It takes no less than an hour for them to extend their hospitable welcome to the Spanish leader thus. ${ }^{3}$

Hospitality is a thoroughly precarious business, and necessarily so. Without the welcome of the stranger or foreigner there would be no hospitality, and yet the welcome is risky. If it were not, that could only be because we already know who we are inviting in, and know also of his good character and intentions. In which case he is not a stranger after all, and our 'hospitality' may not be worthy of the name. This paradox of hospitality, a paradox that, if we could escape it, would undermine hospitality itself, has been highlighted by Jacques Derrida. Derrida reminds us that the guest might be the very devil himself and that, if we want to be hospitable, this is a risk we just have to take.

Yet Derrida spends much more time reflecting on the opposite and equally troubling paradox that the host of hospitality, necessary though he is, also behaves less than angelically both by limiting his welcome and, even when a welcome is offered, extending it only on his own terms. Thus Derrida, and those inspired by his deconstructive approach, have haunted inhospitable hosts with absent or abused guests, and have done so mostly by way of a critique of liberal democracies and their less then generous immigration and asylum policies. ${ }^{4}$ Such approaches are motivated by a desire to critically engage the inequitable character of international politics - utilising the ethics of hospitality for specific ethico-political

\footnotetext{
${ }^{3}$ Hernán Cortés, Letters from Mexico, translated by A.R. Pagden (New York: Grossman, 1971), 84; see also Díaz, The Conquest of New Spain, 216.

${ }^{4}$ See the following exemplary accounts: Mireille Rosello, Postcolonial Hospitality: The Immigrant as Guest (Stanford CA: Stanford University Press, 2001); Mustafa Dikeç, 'Pera Peras Poros: longings for spaces of hospitality', Theory, Culture and Society 19, No.1-2, 2002, 227-47; and Roxanne Lynn Doty, 'Fronteras Compasivas and the Ethics of Unconditional Hospitality’, Millennium 35, No. 1, 2006, 53-74.
} 
interventions. ${ }^{5}$ My own intervention in this debate, which focuses rather on the problem of abused hosts, is similarly intended. Not at all as a fillip for those in rich and powerful states who would reject the claims of hospitality, but rather as a reminder that the little people risk far more, maybe all, in hospitality. There is, in short, a danger of conflating the problems and paradoxes of hospitality with secure and wealthy contemporary democracies. While the rampaging conquistadores who we will turn to shortly may no longer be with us, the problem of the inhospitable guest is surely as pertinent to international hospitality today as in the sixteenth century. To take just one example of this, in Bananas, Beaches and Bases, Cynthia Enloe shows that tourism, as the world's largest industry, has woven patterns of inequality that are doing nothing less than restructuring international politics. ${ }^{6}$ Included in this dense web of inequality is the guest as male sex tourist who explains why 'there are 400,000 more women than men living in Bangkok' and the thousands of military bases where, as in the time of the conquistadores, male guests who get to travel prey on female hosts who don't. ${ }^{7}$

My intention in this article is thus to build on Jacques Derrida's insight that the ethics of hospitality is inseparable from very real decision on the welcome of the foreigner by considering in a more sustained way the problem of the inhospitable (host-harming) guest in the history of international hospitality. In addition to the violence of conditional hospitality, we shall see that unconditional hospitality is violent too, forcing us back on to a politics of hospitality. To drive this point home, I start by retelling the woeful story of Montezuma, Aztec host and then hostage of Cortés and his band of inhospitable Spanish conquistadores in early sixteenth century Mexico. ${ }^{8}$ Why Montezuma? As we shall see, no host has come closer to offering unconditional hospitality and never have the results of hospitality been more

\footnotetext{
${ }^{5}$ Thanks to an anonymous referee for reminding me of the importance of this point.

${ }^{6}$ Cynthia Enloe, Bananas, Beaches and Bases (London: University of California Press, 2000), 20.

${ }^{7}$ Ibid., 35; 'Rape Victim Fights for Justice against U.S. Military, Japan', Japan Times 9 March 2009.

${ }^{8}$ Montezuma's name is now usually rendered as Moctezuma. I stick with the older spelling because most readers will know it this way. Similarly, Montezuma's people are now designated Mexica rather than Aztec.
} 
terrible, indeed genocidal, for a host community. In light of the example of Montezuma, we will revisit Derrida's critique of Immanuel Kant’s limited right of cosmopolitan hospitality, noting that Kant's concern to condition hospitality to a right of visitation only likely reflects his concern that an unlimited hospitality might legitimate the colonising violence of inhospitable European guests, a possibility that Derrida's critique of the inhospitable Kantian host appears to overlook.

In the second half of the article, digging even deeper into the history of hospitality, I recover an ancient concern with the host-harming risks associated with hospitality that Montezuma so tragically exemplifies. What this long-lost discourse on the inhospitable guest suggests is that a genealogy of hospitality, yet to be attempted, would easily dispute the idea of a pure origin or unitary history of hospitality. Like reason, madness and other seemingly enduring things, hospitality is in fact radically discontinuous historically - as we will see when uncovering the profound shift between pre-Homeric and Homeric hospitality as evidenced in The Odyssey and in other traces in the surviving texts of antiquity. Pre-Homeric hospitality, the hospitality of the 'little people’, was motivated by magico-religious xenophobia, literally by fear of strangers; Homeric hospitality by elite fear of the mob in the new city-sates of that era, which drove the elites of antiquity to build political allegiances by showing each other generous hospitality. Thus in antiquity we find two further explanations for why the host-harming history of hospitality has been neglected. First, because it is the hospitality narrative of the little people who, though risking more in offering hospitality, have been marginal in writing its history. Second, because the little people's narrative was overwritten by the Homeric account of hospitality—-the unlimited welcome of heroes by their fellow elites. Offering more but risking less, this aristocratic hospitality narrative no longer portrayed hosting as precarious. 
In conclusion, the deconstructive (Derridean) and genealogical (Foucauldian) perspectives on hospitality considered in parts one and two of the article respectively are brought together. They are found to be complementary - just as deconstruction reveals that hospitality is not consistent with itself conceptually (hospitality calls for a welcome but the welcome might destroy hospitality), genealogy shows that it has been radically discontinuous with itself historically (the welcome of hospitality has signified not only very different but even incommensurable things over time). The end result of this thorough disenchantment of the ethics of hospitality is that the political is brought back into hospitality. Hospitality calls for a welcome, but there is always a decision on the welcome to be made.

\section{Spectres of Hospitality}

At last crossing the bridge into Tenochtitlan, Cortés is taken aback by the broad, straight streets lined on every side with large and beautiful buildings. The main tower, he thinks aloud, is easily higher even than that of the cathedral of Seville. ${ }^{9}$ Immediately he reproaches himself - this is no time to get lost in thought, he must be on his guard. For approaching now, attended by maybe two hundred men, comes Montezuma himself, lord of the Mexica. Cortés dismounts from his horse and advances towards him, only to be stopped by two attendant lords who prevent Cortés from reaching out his hand, making as if Montezuma is not to be touched. To Cortés great surprise, slowly, and without uttering a word, Montezuma too now stretches out to kiss the ground before him. ${ }^{10}$

\footnotetext{
${ }^{9}$ Cortés, Letters from Mexico, 105.

${ }^{10}$ Ibid., 84-5; Díaz, The Conquest of New Spain, 217-8.
} 
Jacques Derrida has argued that ethics is hospitality. ${ }^{11}$ As that which opens up to the face which is to say the uniqueness and irreplaceability - of the Other, the welcome of hospitality is the ethical moment itself. The face as that which is irreducible to a theme - resistant to the totalising effort to reduce the Other to the Same - is the quality which gives the face of the other a 'spectral aura'. ${ }^{12}$ Since the guest, thus described, is the stranger in all his strangeness, true hospitality, on Derrida's reading of ethics, is necessarily unconditional. The domesticating violence, the violence of the host, characteristic of conditional hospitality besmirches the Other-regarding spirit of pure or unlimited hospitality. ${ }^{13}$ Conditional hospitality assimilates, reducing difference to identity; unconditional hospitality speaks rather of a welcome of the Other in all his alterity, in recognition of his transcendence of any theme. ${ }^{14}$ In this hyperbolic register Derrida's unconditional hospitality, which owes much to Emmanuel Levinas, involves the host giving way to the guest, such that the host is paradoxically the host of the guest, his hostage even. ${ }^{15}$ As students of Derrida's aporetic thought will know, however, this is by no means the end of the matter. Just as much as being an ethic of unlimited hospitality in which the door is never closed and whoever comes comes, hospitality cannot only be Other-regarding. An inescapable condition of the door that opens to welcome the Other is a home with a Host. Sovereignty become as necessary to hospitalityethics as it is irreducible to it. ${ }^{16}$ The at-home of hospitality cannot survive hospitality's unlimited form.

\footnotetext{
${ }^{11}$ Jacques Derrida, On Cosmopolitanism and Forgiveness, translated by M. Dooley and M. Hughes (London: Routledge, 2001), 17. See also Jacques Derrida, Adieu: to Emmanuel Levinas, translated by P-A. Brault and M. Nass (Stanford CA: Stanford University Press, 1999), 50.

12 Derrida, Adieu, 110.

13 Ibid., 15.

${ }^{14}$ Gideon Baker, 'Cosmopolitanism as Hospitality: revisiting identity and difference in cosmopolitanism', Alternatives 34, No. 2, 2009, 107-28.

${ }^{15}$ Derrida, Adieu, 55.

${ }^{16}$ Gideon Baker, 'The Politics of Hospitality: sovereignty and ethics in political community', in The Future of Political Community, eds. Gideon Baker and Jens Bartelson (London: Routledge, 2009).
} 
However, though the at-home may be 'necessary' to it, hospitality continues to call for an unlimited welcome. In other words, hospitality is a 'self-contradictory' concept which 'selfdeconstructs'. ${ }^{17}$ The welcome of hospitality is nothing less than the deconstruction of the athome on which it depends. For the home is a usurpation, a necessary but violent aspect of being - a taking the place of the Other whose face calls into question, contests even, my possession. ${ }^{18}$ This contestation of possession is also the host put into question, which brings us back to the idea of the host as hostage. ${ }^{19}$ My dwelling, in short, is haunted; there would indeed 'be no hospitality without the chance of spectrality'. ${ }^{20}$ As Anne Dufourmantelle neatly summarises it: alerting us to, and troubling us with, this spectral aspect of the home is then Derrida's key contribution to our thought of hospitality: 'To the pacified reason of Kant [to whom we shall return], Derrida opposes a primary haunting of a subject prevented by alterity from closing itself off in its peacefulness'. ${ }^{21}$ Thus 'Only an unconditional hospitality can give meaning and practical rationality to a concept of hospitality'; ${ }^{22}$ the principle of hospitality 'demands, it even creates the desire for, a welcome without reserve and without calculation, an exposure without limit to whoever arrives'. ${ }^{23}$

Cortés follows behind Montezuma. Montezuma stops and turns; closing the gap between the two men in a few strides he reaches up and places around Cortés neck two collars made from the prized shells of periwinkles. Dangling from each collar are eight gold shrimps, about a foot and a half in length. Continuing down the street, they arrive at a palace. As Cortés wrote later of this palace in a letter to his King, it was 'very large and beautiful' and 'had been very

\footnotetext{
${ }^{17}$ Jacques Derrida, 'Hostipitality’ Angelaki 5, No. 3, 2000, 5.

${ }^{18}$ Derrida, Adieu, 16 and 41-2.

19 Ibid., 56.

${ }^{20}$ Ibid., 112.

${ }^{21}$ Anne Dufourmantelle, 'Invitation', in Jacques Derrida, Of Hospitality, translated by R. Bowlby (Stanford CA: Stanford University Press, 2000), 4.

${ }^{22}$ Jacques Derrida, 'The World of the Enlightenment to Come (Exception, Calculation, Sovereignty)', Research in Phenomenology 33, 2003, 40.

${ }^{23}$ Jacques Derrida, 'The Principle of Hospitality’, Parallax 11, No. 1, 2005, 6.
} 
well prepared to accommodate us'. ${ }^{24}$ Taking Cortés by the hand, Montezuma leads him into a spacious chamber and, after declaring 'you and your brothers are in your own house. Rest awhile', asks him to await his return there. ${ }^{25}$ As Cortés recounted 'he returned with many and various treasures of gold and silver and featherwork, and as many as five or six thousand cotton garments, all very rich and woven and embroidered in various ways', all of which Montezuma presented to his guest. ${ }^{26}$

The haunting of limited hospitality by unlimited hospitality, of the host (Same) by the guest (Other), has been recounted often by Derrida, for example in relation to the limits on hospitality of Immanuel Kant’s right of cosmopolitan hospitality and also in relation to asylum in liberal democratic states. With regard to Kant, for whom in Perpetual Peace (1795) cosmopolitan hospitality meant the 'right of a stranger not to be treated with hostility when he arrives on someone else's territory', ${ }^{27}$ Derrida has questioned whether Kant's identification of hospitality with right, specifically with a universal right of visitation rather than residence ('He [the stranger] can indeed be turned away, if this can be done without causing his death ${ }^{28}$ ), does not 'violently impose a contradiction on the very concept of hospitality in fixing a limit to it, in de-termining it...'? ${ }^{29}$ Turning hospitality into a right of visitation only makes a more substantive welcome dependent on special agreements between states for Kant, which is also to say a right only for citizens of states. ${ }^{30}$ Kantian hospitality, in being restricted to the space of right, becomes a revocable gift of the state and dependent therefore on sovereignty, law and the state police. ${ }^{31}$ More than this, it is quite possible,

\footnotetext{
${ }^{24}$ Cortés, Letters from Mexico, 85.

${ }^{25}$ Díaz, The Conquest of New Spain, 219.

${ }^{26}$ Cortés, Letters from Mexico, 85.

${ }^{27}$ Immanuel Kant, 'Perpetual Peace: a philosophical sketch', in ed. H.S. Reiss, Kant's Political Writings (Cambridge: Cambridge University Press, 1991), 105.

${ }^{28}$ Ibid., 105-6.

${ }^{29}$ Derrida, 'Hostipitality', 4.

${ }^{30}$ Derrida, Adieu, 87.

${ }^{31}$ Derrida, 'Hostipitality', 3; Derrida, On Cosmopolitanism, 22; Derrida, Adieu, 68.
} 
Derrida points out elsewhere, to imagine a political peace (Kant's cosmopolitan right of hospitality is in the service of 'perpetual peace', for Kant sees peace as a political possibility in contradistinction to 'natural' hostility) between two states where no hospitality would be offered to citizens of the other state. 'In fact, this is what most often happens'. ${ }^{32}$ Ultimately states, as much communities of states as in Kant's republican schema for perpetual peace, can only limit hospitality. A hospitality predicated on the state can only ever be about defining hospitality's limitations and conditions in the manner of Kant since no state ever will practice unconditional hospitality. ${ }^{33}$ Thus the cosmo-political or inter-state hospitality of Kant will continue to be haunted by the millions of those without papers and homes who 'call out for another international law, another border politics... indeed [for] a [hospitality] that effectively operates beyond the interests of the nation-States'. ${ }^{34}$

But what of those who are given refuge in states? Have they not received hospitality? The Kantian welcome, being cosmopolitical rather than transnational or universal, which is to say 'purely political and juridical, civil and state (always determined by citizenship)', turns the foreigner who comes from a guest treated as a friend into a subject of the law - someone with whom, like an enemy, 'to receive him, you begin by asking his name; you enjoin him to state and to guarantee his identity, as you would a witness before a court' ${ }^{35}$ The Kantian host thereby 'sets up his relationship to the one who is in his house as a matter of law, in the same

\footnotetext{
${ }^{32}$ Derrida, Adieu, 86.

${ }^{33}$ Ibid., 89-90. In further support of this point, Derrida argues (in On Cosmopolitanism, 20-1) that Kant's claim of common possession of the surface of the earth in Perpetual Peace is posited 'above all to expel from it [the earth's surface] what is erected, constructed, or what sets itself up above the soil: habitat, culture, institution, State etc'. It is thanks to this exclusion of the State from the soil on which its rests, suggests Derrida, that Kant is able to articulate a hospitality of exclusions: one limited to visitation and defined by (state) right.

${ }^{34}$ Derrida, Adieu, 101. In an interesting reversal of Derrida's critique of Kant here, La Caze pursues a Kantian critique of Derridean hospitality by arguing that Derrida's substitution of hospitality as ethics for hospitality as right 'makes practical measures for asylum seekers and refugees dependent on goodwill, rather than putting a set of structures, based on right, in place' (Marguerite La Caze, 'At the Intersection: Kant, Derrida, and the relation between ethics and politics' Political Theory 35, No. 6, 2007, 794).

${ }^{35}$ Derrida, Adieu, 68; Derrida, Of Hospitality, 27.
} 
way as he also does the relationships linking him to murderers, the police, or judges'. ${ }^{36}$ 'Does hospitality consist in interrogating the new arrival?' thus, Derrida asks. ${ }^{37}$ And he knows, and we know, that it should not.

The tradition of which Kant's Perpetual Peace is the 'most powerful' statement is thus open to interpretation, Derrida argues, as implying a less than generous welcome; for example of asylum seekers by liberal democratic states. ${ }^{38}$ In asylum policy in particular, there is a 'considerable gap separating the great and generous principles of the right to asylum inherited from the Enlightenment thinkers ... and the historical reality or the effective implementation of these principles'. ${ }^{39}$ The haunting of conditional with unconditional hospitality in relation to asylum is enacted in Derrida's address to the International Parliament of Writers (IPW). Derrida responds in this address to the IPW's Network of Cities of Asylum which, following the Salman Rushdie affair, was established to provide safe havens for persecuted writers. The European Charter of Cities of Asylum, launched in Strasbourg, proposed that this city 'offer Salman Rushdie the freedom of the city and declare itself a "City of Asylum” for persecuted intellectuals'. Derrida's challenge to the IPW is to recall Hannah Arendt's observation that, just as a dog with a name has a better chance of survival than a stray, so a famous refugee is much more likely to be afforded the protection of a state than an unknown one. ${ }^{40}$ Noting the particular relevance of this remark to a network seeking refuge for writers with an international profile, Derrida raises the spectre of 'the foreigner in general, the immigrant, the exiled, the deported, the stateless or the displaced person'. To cite only 'the best known would risk sending the anonymous others back into the darkness from which they find it hard

\footnotetext{
${ }^{36}$ Derrida, Of Hospitality, 27 and 71-3.

${ }^{37}$ Ibid., 27.

${ }^{38}$ Derrida, On Cosmopolitanism, 22.

39 Ibid., 11.

40 Ibid., 15.
} 
to escape, a darkness which is truly the worst and the condition for all others' ${ }^{41}$ The sovereign host of hospitality, on this account, is haunted by the absent guest, conditional by unconditional hospitality.

Having presented Cortés with gifts of gold, silver and finely woven cloth, Montezuma turned and spoke to his guest. Cortés' retelling of what he said, in which guest is reworked into host and host into guest, was no doubt partly intended to ward off posterity's judgement on him as amongst the worst guests in history:

For a long time we have known from the writings of our ancestors that neither I, nor any who dwell in this land, are natives of it, but foreigners who came from very distant parts; and likewise we know that a chieftain, of whom they were all vassals, brought our people to this region. ... And we have always heard that those who descended from him would come and conquer this land and take us as their vassals. ... ... So be assured that we shall obey you and hold you as our lord in place of the great sovereign of whom you speak... Thus, as you are in your own country and your own house, rest now from the hardships of your journey and the battles which you have fought... ${ }^{42}$

\footnotetext{
${ }^{41}$ Ibid., 6.

${ }^{42}$ Cortés, Letters from Mexico, 85-6. As Georg Cavallar notes, 'historians have demonstrated how implausible these words are, reflecting the Gospels and standard European legal formulas rather than the authentic speech of an Amerindian "emperor" ... Cortés account was, in short, an attempt to legitimize the conquest as morally and legally rightful' (Georg Cavallar, The Rights of Strangers: theories of international hospitality, the global community, and political justice since Vitoria (Aldershot: Ashgate, 2002), 79). J.H. Elliot also draws our attention to the fact that, "Whatever its origins, the story of the expected return of lords from the east was essential to Cortés grand design, for it enabled him to allege and explain a "voluntary" submission of Montezuma, and the "legal” transfer of his empire' directly to Charles V (J.H. Elliot, 'Cortés, Velázquez and Charles V', in Cortés, Letters from Mexico, xxviii). This legal fiction was necessary to Cortés' appeal to the Spanish King over the head of his patron, Velázquez (who, unlike Cortés, was legally entitled by the Spanish Crown to subjugate new dominions), in order to legitimate retrospectively his (Cortés') fait accompli in conquering Mexico without Velázquez’s permission.
} 
Something is lurking in the shadows of accounts which haunt conditional hospitality with the absent guest - accounts such as those which Derrida gave to the IPW or with regard to Kant. This ethereal presence is here called the spectre of Montezuma, a ghost who, reversing the narrative provided by Derrida, represents the haunting of unconditional hospitality with the absent (in Montezuma's case: kidnapped, detained, murdered) host. This alternative history of hospitality, as we shall see, is there to be retrieved. It can be found in the very earliest reflections on hospitality, in the Odyssey, to which we will return, and also in its Roman equivalent, the Aeneid. It is found also in the writings of those, such as Bartolome de Las Casas, author of A Short History of the Destruction of the Americas (1552), who have protested the usurping violence of guests rather than the assimilating violence of hosts. Las Casas, a contemporary of, and witness to, the Spanish conquests throughout the Americas, frames his polemic against the conquistadores in terms of the cruel usurpations of guests shown generous hospitality by their hosts. In just one of many such tales of inhospitality he recounts that,

Since all the settlements of the Indians in this fertile land were situated in the midst of gardens and orchards, the Christians resided in them, each Christian taking over the houses of the Indians who had been allocated to him according to the royal grant known as the encomienda. The Indian who had owned the house now worked for the Christian as his servant, cooking his meals, tilling the soil, working without rest. Oh, the pitiful Indians! Men and women, the aged and the children all worked for this Spanish Christian. For the children, as soon as they could stand on their legs, were put 
to work. And thus the Indians have been used up and consumed, and the few who survive are still being wasted away. ${ }^{43}$

We shall revisit the idea of guests ‘using up’ the host’s substance, for despite finding an unwarranted echo in contemporary rhetoric against asylum seekers and refugees, it seems long to have been of genuine concern to those who recognise, as xenophobes do not, the claims of hospitality. ${ }^{44}$ Returning for now to Las Casas’ concern for non-European hosts, such concern can be found also in Kant's Perpetual Peace. As we have seen, Kant's right of universal hospitality as outlined in this text is a right of global reach but limited scope. But this was in part precisely because Kant knew that limitations on the right of hospitality were necessary to prevent such a right being abused by European colonisers.

As Brown has argued, in his critique of Kant Derrida neglects the historical context within which Kant wrote. ${ }^{45}$ Brown rightly observes that Derrida often talks of hospitality as if the moral complexities associated with it play out exclusively in the relationship between liberal democratic states and the 'wretched of the earth' who seek refuge in them. Yet as Brown reminds us, Kant is operating much closer to an intellectual context represented by thinkers such as Las Casas and Vitoria who, responding to European conquests in the New World, talked of the laws of hospitality in the context of the rights of the visited as much as those of the visitor. Brown thus recalls that Kant wrote that the

\footnotetext{
${ }^{43}$ Bartolome de Las Casas, The Devastation of the Indies: a brief account, translated by H. Briffault (London: John Hopkins University Press, 1992), 50.

${ }^{44}$ It is important to clarify that the discussion here surrounds a host who accepted the claim, not only of hospitality, but of unconditional hospitality.

${ }^{45}$ Garrett W. Brown, 'The Laws of Hospitality, Asylum Seekers and Cosmopolitan Right: a Kantian response to Jacques Derrida’, European Journal of Political Theory 9, No. 3, 2010.
} 
inhospitable conduct of the civilised states of our continent, especially the commercial states, the injustice which they display in visiting foreign countries and peoples (which in their case is the same as conquering them) seems appallingly great. ${ }^{46}$

It was for this reason also, it seems, that Kant endorsed China and Japan's attempt to limit their hospitality to visitation only - any additional entitlement to reside in these countries would require a mutually consistent agreement between the visitor and the visited. Kant's limitation on hospitality, Brown argues, therefore represents 'not an effort to promote a xenophobic nationalism', but rather 'an attempt to limit imperial colonialism abroad'. ${ }^{47}$

On Cortés telling, three days after guests are supposed, like fish, to begin to stink (that is, after six days), consideration of the guest's security and of the interests of the King of Spain (being the same) led him to contemplate taking Montezuma into his power: ${ }^{48}$ 'In order that he should not retreat from the willingness he showed to serve Your Majesty; but chiefly because we Spaniards are rather obstinate and persistent.... ${ }^{49}$ Cortés himself, it seems, was well aware that his band of inhospitable conquistadores had began to smell. Security was uppermost in Cortés mind since he knew that Montezuma, while avowing unconditional hospitality, could be sovereign if he chose to be. Cortés had noted 'that if the inhabitants of the city wished to betray us they were very well equipped for it by the design of the city, for once the bridges had been removed they could starve us to death without our being able to reach the mainland' ${ }^{50}$ The Spanish were also, of course, hugely outnumbered. Incarcerating

\footnotetext{
${ }^{46}$ Kant, 'Perpetual Peace’, 106.

${ }^{47}$ Brown, 'The Laws of Hospitality, ?.

${ }^{48}$ Las Casas disputes Cortés' claim of a six day hiatus, claiming that, on the very day they arrived, 'the Spaniards deceitfully set a guard of eighty men to capture the great King Montezuma and put him in chains' (The Devastation of the Indies, 61). Either way, we know from Cortés himself that the very purpose of his expedition was to 'take him [Montezuma] alive in chains or make him subject to Your Majesty’s Royal Crown' (Letters from Mexico, 50).

${ }^{49}$ Cortés, Letters from Mexico, 88.

${ }^{50}$ Ibid., 84. See also Díaz, The Conquest of New Spain, 242.
} 
Montezuma was therefore deemed necessary since, 'should we annoy him he might, as he is so powerful, obliterate all memory of us' ${ }^{51}$ Of course, the guests were also determined to be hosts, and Cortés did not even pretend to deny that 'Furthermore, by having him with me, all those other lands which were subject to him would come more swiftly to the recognition of Your Majesty, as later happened. I resolved, therefore, to take him and keep him in the quarters where I was, which were very strong, ${ }^{52}$ With such reasons of security and raison d'état weighing heavily on his mind, Cortés decided that he must act, and act fast.

The neglected history of hospitality teaches us that unconditional hospitality, such as that which Montezuma showed to Cortés, can unleash an annihilating violence in which sovereignty and identity, much more than being 'problematised', are obliterated in an orgy of violence. The ghost of Montezuma reminds us that unlimited hospitality is haunted too. The Spanish, totalling around 300 men, ${ }^{53}$ were outnumbered a thousand to one; Montezuma could have prevailed and his homeland could have survived, at least for a time, if he had not offered an unconditional welcome. Even though he does not dwell on it in the way that he does the haunting of conditional hospitality, Derrida is very aware that conditional hospitality is haunted too. We noted earlier the occasion where Derrida states that the principle of hospitality 'demands, it even creates the desire for, a welcome without reserve and without calculation, an exposure without limit to whoever arrives'. But his next sentence is this:

Yet a cultural or linguistic community, a family, a nation, can not not suspend, at the least, even betray this principle of absolute hospitality: to protect a 'home', without

\footnotetext{
${ }^{51}$ Cortés, Letters from Mexico, 88.

52 Ibid., 88.

${ }^{53}$ Ibid., 50. Díaz says 400 (The Conquest of New Spain, 216).
} 
doubt, by guaranteeing property and what is 'proper' to itself against the unlimited arrival of the other... ${ }^{54}$

For the most part, Derrida points up this aporia in the name of unconditional hospitality itself, noting that without conditional laws of hospitality, unconditional hospitality remains 'a pious and irresponsible desire, without form and without potency’: ${ }^{55}$

If the two meanings of hospitality remain irreducible, it is always in the name of pure or hyperbolic hospitality that it is necessary, in order to render it as effective as possible, to invent the best arrangements, the least bad conditions, the most just legislation ... It is often forgotten that it is in the name of unconditional hospitality (which gives its meaning to all welcoming of the foreigner) that we must try to determine the best conditions, that is to say some particular legislative limits, and especially a particular application of the laws. ${ }^{56}$

Yet Derrida also acknowledges that the guest may contest my being-at-home even to the extent of bringing death and destruction to it; the one who comes may be the very 'figure of evil' ${ }^{57}$ Of course, as we have seen, this double-bind is inescapable since 'this possible hospitality to the worst is necessary so that good hospitality can have a chance'. ${ }^{58}$ However, the host's exposure to harm, while necessary, is also necessarily limited since an unlimited

\footnotetext{
${ }^{54}$ Derrida, 'The Principle of Hospitality, 6.

${ }^{55}$ Derrida, On Cosmopolitanism, 23.

${ }^{56}$ Derrida, 'The Principle of Hospitality, 6-7, emphasis added. See also Derrida Adieu, 48.

${ }^{57}$ Jacques Derrida, Aporias (Stanford CA: Stanford University Press, 1993), 12. Jacques Derrida, 'Perhaps or Maybe', in 'Responsibilities of Deconstruction', eds. J. Dronsfield and N. Midgley, Warwick Journal of Philosophy 6, Summer, 1997, 9.

${ }^{58}$ Derrida, Adieu, 35. Hospitality as welcome of the stranger means that hospitality cannot wait until the character and intentions of the guest are known. For this very reason, it 'is thus necessary, beyond all perception, to receive the other while running the risk, a risk that is always troubling, strangely troubling, like the stranger (unheimlich), of a hospitality offered to the guest as ghost or Geist as Gast' (Ibid., 111).
} 
hospitality, capable as it is of 'being perverted at any moment', clears the field for harm doers to do their worst: ${ }^{59}$

Left to itself, the incalculable and giving idea of justice is always very close to the bad, even to the worst, for it can always be appropriated by the most perverse calculation ... And so incalculable justice requires us to calculate. ${ }^{60}$

This notion that, left to itself, incalculable justice (which, for Derrida, is the same thing as unconditional hospitality) is not only dangerous but reckless or, better, irresponsible, is important and needs unpacking further. Why, exactly, is unconditional hospitality not only dangerous but wrong? Because it forgets that even the absolute non-violence, or giving-way, to the Other of unconditional hospitality would reintroduce the violence of injustice through the absolute prioritisation of the Other who comes over all the others, not to mention the violence that unconditional hospitality threatens to myself as host, to 'myself as Other'. Thus while Derrida arguably underplays the spectre of Montezuma, he is, as we have seen, very far from unaware of the double-bind of hospitality. And indeed, this reverse haunting is really just the other side of the Derridean aporia of hospitality - since limited hospitality is as irreducible as unlimited hospitality, since each contaminates the other, we would expect the host to haunt all taking of hospitality by the guest (just as withholding hospitality leads to the host being haunted by the guest).

That night, Cortés went with armed men to Montezuma’s palace, demanding on pain of death that Montezuma return, quietly in order not to raise the alarm, as hostage to their quarters. ${ }^{61}$

\footnotetext{
${ }^{59}$ Derrida, On Cosmopolitanism, 23.

${ }^{60}$ Jacques Derrida, 'Force of Law: “The Mystical Foundation of Authority”', Cardozo Law Review, 921, 1990, 971.
} 
Montezuma, after being refused his request that they spare him this disgrace and instead take his son and daughters, eventually agreed to be taken. At this his nobles stripped off their robes and, weeping, brought a litter on which he was carried, in shocked silence, through the streets to the new quarters that were to be the scene of his house arrest. ${ }^{62}$ Somehow word got out and the alarm was raised. But Montezuma, ever the exemplary host, issued orders forbidding any movement in the city and indicating that he had gone with the Spanish of his own free will. ${ }^{63}$ Mindful of his hosts need for food as well as quiet, Montezuma also ordered victuals. And, sure enough,

when dawn came, the crier called for all of the things needed: white tortillas, fried chickens, hens' eggs, clean water, firewood, charcoal. ... [For] this was what Moctezuma had ordered. And when he summoned the nobles, they no longer paid attention to him, but rather, they were angry; they no longer accepted him; they no longer acted on his behalf; he was no longer obeyed. However, they gave [the Spaniards] everything they required - food, water, and fodder for the horses. ${ }^{64}$

The implication of this account is that Mexica hospitality was not limited to obeying Montezuma's orders, continuing even when he himself was no longer in command. Regardless, the treachery of the Spanish guests towards their hosts had only just begun. With Montezuma imprisoned and Cortés campaigning elsewhere, the remaining conquistadores,

\footnotetext{
${ }^{61}$ Díaz, The Conquest of New Spain, 246-7. Cortés, unsurprisingly, tells a sanitised version of this story which is still staggering in the insight it provides into his assumption of sovereignty even while a guest in somebody else's land. Thus, according to Cortés', Montezuma is 'asked' to stay in the Spanish quarters 'until the truth [of his knowledge of an attack on a Spanish garrison elsewhere] were known and he was shown to be blameless'. To this 'request', Montezuma is said only to have 'discussed' it with Cortés before agreeing to go (Cortés, Letters from Mexico, 89-90).

${ }^{6}$ Cortés, Letters from Mexico, 90.

63 Ibid., 90; Díaz, The Conquest of New Spain, 247.

${ }^{64}$ Bernardino de Sahagún, The Florentine Codex: A General History of the Things of New Spain. Book 12-The Conquest of Mexico, translated by A.J.O. Anderson and C.E. Dibble (Salt Lake City: University of Utah Press, 1960), Chapter 17.
} 
with Cortés permission according to Las Casas, decided to 'commit an outstanding crime, with the aim of increasing and spreading terror throughout the land, using their utmost methods of cruelty' ${ }^{65}$ The ensuing massacre is recounted in gruesome detail both by Las Casas and by a Mexica primary source as retold in de Sahagún's The Florentine Codex:

Here it is told how the Spaniards murdered the Mexicas who were celebrating the Fiesta of Huitzilopochtli in the place they called The Patio of the Gods. At this time, when everyone was enjoying the fiesta, when everyone was already dancing, when everyone was already singing, when song was linked to song and the songs roared like waves, in that precise moment the Spaniards determined to kill people. [T]hey surrounded those who danced ... attack[ing] all the people, stabbing them, spearing them, wounding them with their swords. ... Some tried to escape, but the Spaniards murdered them at the gates while they laughed. Others climbed the walls, but they could not save themselves. ... The blood of the warriors ran like water as they ran, forming pools, which widened, as the smell of blood and entrails fouled the air... ${ }^{66}$

On Cortés' hurried return to Tenochtitlan, the Mexica uprising sparked off by this massacre had surprisingly ceased and the streets were quiet. According to Díaz, this was thanks to Montezuma himself, who 'had pacified his people and made them give up the attack' ${ }^{67}$ Las Casas agrees that Montezuma 'came out into the corridors of the palace and commanded the Indians to go away in peace' ${ }^{68}$ There was a heavy price to pay for this unwarranted act of

\footnotetext{
${ }^{65}$ Las Casas, The Devastation of the Indies, 62. Díaz's account of the massacre states that de Alvarado, who Cortés had left in charge, acted of his own accord in order to 'surprise and scare' the Mexicas who he claimed to have been forewarned were plotting an attack (The Conquest of New Spain, 283 and 286). Cortés, meanwhile, states that the Spanish were attacked first, which no other source agrees with (Letters from Mexico, 128).

${ }^{66}$ de Sahagún, The Florentine Codex, Chapter 20. This account is similar to that provided in Las Casas, The Devastation of the Indies, 60-3.

${ }^{67}$ Díaz, The Conquest of New Spain, 285.

${ }^{68}$ Las Casas, The Devastation of the Indies, 63.
} 
unconditional hospitality, however. The leader of the revolt 'set his dagger against [Montezuma's] breast and they all swore henceforth not to obey him and that they would consult together and elect another lord who would guide them in their battles'. ${ }^{69}$ When, shortly after, the battle for the city (Las Casas calls it the Mexica's 'righteous war, ${ }^{70}$ ) did indeed resume under new leadership, the fighting was bitter. Montezuma himself fell in this new round of fighting, mortally wounded in a hail of stones and arrows fired by his own people. Our two sources (both Spanish) disagree as to whether he was in the thick of the fighting of his own accord or having been persuaded by Cortés, but both sources agree that he was once again appealing to his kinsmen for a cessation of the fighting, that the hard-pressed Spaniards might go free. ${ }^{71}$ If Las Casas’ account is correct (though Cortés and Díaz’s versions differ), a truce was eventually agreed, and, fatally for the inhabitants of Tenochtitlan, Cortés lived to fight another day. When he returned, this time with a much larger army, the Spanish

created great havoc. In this strange and admirable kingdom of the Indies, they slew a countless number of people and burned alive many great chiefs ... inflict[ing] extraordinary abominations on the city Of Mexico and the other cities and towns, over a surface of fifteen Or twenty leagues, killing countless Indians ... ${ }^{72}$

Montezuma's ghost, haunting unconditional hospitality, reminds us that the violence which unlimited hospitality threatens can destroy hospitality itself, replacing guest-friendship

\footnotetext{
${ }^{69}$ Ibid., 12.

70 Ibid., 12.

${ }^{71}$ Cortés, Letters from Mexico, 151; Díaz, The Conquest of New Spain, 293-4.

${ }^{72}$ Las Casas, The Devastation of the Indies, 64.This is not disputed by either Cortés (Letters from Mexico, 264) or Díaz (The Conquest of New Spain, 405), who, using strikingly similar language, describe respectively 'such piles of dead that we were forced to walk upon them' and that 'we could not walk without treading on the bodies and heads of dead Indians'. Pagden observes that it is impossible to compute the number of Mexica dead, with estimates ranging from 240,000 to 100,000, though this latter figure takes no account of countless deaths from smallpox in the first of the New World pandemics which also took hold at this time (in Letters from Mexico, 491, n 77).
} 
(xenia) and peace with xenophobia and war, sometimes for many generations to come. And this is indeed an ancient problem - the very stuff of The Odyssey, The Iliad and The Aeneid, as we shall now see. As told in the Aeneid, in the aftermath of the treachery and inhospitality of her guest Aeneas, Dido, Queen of Carthage, falls on her sword. Her suicide echoes the devotio of a defeated Roman commander who takes his own life to commit the gods to take revenge on his enemy. ${ }^{73}$ Thus the dying Dido issues a curse against the city which Aeneas’ descendants will found, committing Carthage to eternal war with Rome:

This is my prayer, my funeral cry - I pour it out with my own lifeblood. And you, my Tyrians, harry with hatred all his line, his race to come: make that offering to my ashes, send it down below. No love between our peoples, ever, no pacts of peace! Come rising from my bones, you avenger still unknown, to stalk those Trojan settlers, hunt with fire and iron, now or in time to come, whenever the power is yours. Shore clash with shore, seas against sea and sword against sword - this is my curse - war between all our people, all their children, endless war! ${ }^{74}$

In Purcell's opera Dido and Aeneas, Purcell has Dido lament 'remember me but forget my fate’. Montezuma’s revenge may have proved less terrible than Dido’s curse, yet when remembering him we cannot forget his fate. Not forgetting Montezuma here signifies the necessity of conceiving of hospitality as a politics of welcoming the stranger. Given the

\footnotetext{
${ }^{73}$ Ned Lebow, 'Homer, Virgil and Identity in International Relations', in The Future of Political Community, 160.

${ }^{74}$ Virgil, The Aeneid, translated by W.F. Jackson (London: Penguin, 1956), 4.774-84.
} 
instability of the concept of hospitality which deconstruction demonstrates, hospitality itself can never point the way when strangers knock at the door. While the face of the Other calls for - even demands - a welcome, there is always a decision on the welcome to be made. Hospitality can haunt, but it cannot guide.

\section{Towards a Genealogy of Hospitality}

Another way of demonstrating the irreducibly political aspect of hospitality goes via a genealogy of hospitality. This has not yet been attempted. Genealogy, Michel Foucault tells us, is characterised by opposition to the search for origins, unity and teleology in history. Taking origins, first, genealogical analysis finds at the historical beginning of things - things, like hospitality, 'that continue to exist and have value for us'- not 'lofty origins' or ‘inviolable identity’ but disparity and accident, emergences for which no one is responsible, in which 'no one can glory' and which are 'capable of undoing every infatuation'. ${ }^{75}$ In terms of the history of things, genealogy finds not 'linear development', 'words that keep their meaning', 'the gradual curve of evolution', 'the meta-historical deployment of ideal signification', or 'immobile forms that precede the external world of accident and succession'. Instead of the enduring essence of things or unbroken continuity, genealogy notes the role of chance and vicissitude in history, the 'invasions, struggles, plundering, disguises, ploys', 'ancient proliferation of errors', 'unsteady victories and unpalatable defeats', the 'dispersion of forgotten things', and the 'endless play of dominations'. ${ }^{76}$ As with deconstruction, genealogy is therefore 'directed against identity', fragmenting that which 'was thought unified', revealing 'the heterogeneity of what was imagined consistent with itself'. ${ }^{77}$

\footnotetext{
${ }^{75}$ Michel Foucault, 'Nietzsche, Genealogy, History', in Language, Counter-Memory, Practice: Selected Interviews and Essays, ed. D.F. Bouchard (Ithaca: Cornell University Press, 1977), 146; 142-3; 150.

${ }^{76}$ Ibid., 139-54.

${ }^{77}$ Ibid., 160; 147.
} 
In what follows I show that hospitality is rich pickings for a genealogical study. Foucault's examination of reason led him to learn that it was born from that 'altogether "reasonable", thing - chance. So too shall we see that hospitality emerged from something altogether inhospitable - magico-religious fear of strangers; in a word, from xenophobia. Initial genealogical investigations into the history of hospitality also easily reveal that hospitality lacks a unitary history, witnessing many discontinuities such as the overwriting of popular by aristocratic hospitality in antiquity which is also the subject of this section. Given that genealogy 'operates ... on documents which have been scratched over and recopied many times’, The Odyssey seems like a good place to start our investigations. ${ }^{78}$

Like a doppelganger of Immanuel Levinas’ Totality and Infinity, which Derrida has claimed 'bequeaths to us an immense treatise of hospitality', The Odyssey passes down an epic tale of inhospitality. ${ }^{79}$ Central to the latter's narrative, and especially to its gory dénouement, is the terrible judgement passed, and finally executed, on the suitors of Odysseus' wife, Penelope. And for what are the suitors condemned? Not for wanting Penelope's hand, but rather for their wanton wasting of their absent host's estate, which is his very substance. Repeatedly, throughout the epic, the suitors are described as wasters; in taking over Odysseus' household and living off his estate they have carried out a 'gross perversion of the convention of xenia' or guest friendship. ${ }^{80}$ Early on in the epic, Odysseus’ son, Telemachus, reports of these Suitors:

\footnotetext{
${ }^{78}$ Ibid., 139.

${ }^{79}$ Derrida, Adieu, 21. Emmanuel Levinas, Totality and Infinity: an essay on exteriority, translated by A. Lingis (Pittsburgh: Duquesne University Press, 1969).

${ }^{80}$ P. Jones, 'Introduction', in Homer, The Odyssey, translated by E.V. Rieu (London: Penguin, 2003), xxiv.
} 
They slaughter our oxen, our sheep, our fattened goats; they feast themselves and drink our sparkling wine - with never a thought for all the wealth that is being wasted. The truth is there is no one like Odysseus in charge to purge the house of this blight. We are not able to defend ourselves: we would prove miserably weak, quite untrained to fight. ${ }^{81}$

And yet the blood-soaked conclusion of The Odyssey, when Odysseus finally slaughters the suitors with terrible vengeance and cruelty, had long puzzled scholars. The extreme bitterness of this protracted scene seems decidedly out of harmony with the rest of the epic, not to mention that the suitors' behaviour is very far from what we know of the courtship customs of the Greeks. Harry Levy offered a compelling resolution of this puzzle, one which brings the ghost of Montezuma out of the shadows of pre-history. Levy hypothesised that the suitor story as we have it resulted from the reworking of an earlier tale into the epic: 'I posit the early existence of a motif which I shall call “The Unjust Guests Outstay Their Welcome and Impoverish Their Host”, ${ }^{82}$ Levy attributed this motif to the 'little tradition', a 'country folk' tradition in contrast to the 'great tradition' of the noble class which later informed the literate and scholarly sections of society, such as Homer, who crafted The Odyssey. ${ }^{83}$ Levy postulated that, transposed to The Odyssey, this theme from the world of little people ('hardworking and frugal farmers') clashed 'with the courtly tradition of the warrior princes, for whom lavish and open-handed hospitality was a dominant cultural mode' ${ }^{84}$ Given this

\footnotetext{
${ }^{81}$ Homer, The Odyssey, 2.55-61. See also: 4.317-18; 20.262-3; 13.426-7; 14.93-6; 17.531-7; 21.69-72; 20.37580; 22.34-8; 22.55-59.

${ }^{82}$ Harry L. Levy, 'The Odyssean Suitors and the Host-Guest Relationship', Transactions and Proceedings of the American Philological Association, 94, 1963, 147.

${ }^{83}$ Ibid., 147.

${ }^{84}$ Ibid., 147.
} 
courtly tradition and its culture of unconditional hospitality, 'the wasters could no longer be presented as mere guests, but had to be assigned a different role': ${ }^{85}$

Given the presence of a queen with an absent spouse, the poet, as I reconstruct the process, transmuted the figures of wasteful guests into those of importunate suitors. But the emotion-laden denouement which I shall try to show was appropriate to the early form of the tale was too deeply embedded in the story to be discarded. Conflated with the theme of a returning hero's identification by a test of strength, it resulted in the story of the massacre as we have it. ${ }^{86}$

Levy argued, pointing to further evidence in the Iliad, that the contrast between the 'great' and 'little' traditions, which here maps onto that between unlimited and limited hospitality, is perceived in the two strikingly different ways in which the theme of the stranger seeking shelter is handled in the Odyssey. ${ }^{87}$ It is well to receive the stranger generously as he may be a god in disguise (indeed, Zeus himself, as both father of the gods and, as Zeus Xenios, the divinity associated with strangers and the guest-friendship that should be shown to them ${ }^{88}$ ), testing the host's hospitality. But for the little people this means that hospitality is prudent, while for the aristocratic tradition it implies reverence of the gods, of the will of Zeus. The aristocratic tradition implies a boundless hospitality, hospitality as piety; the little tradition a limited hospitality, hospitality as necessary but dangerous. And indeed, for Levy, it is for this reason that the little tradition marries the motif of obligation of host to guest with 'a

\footnotetext{
${ }^{85}$ Ibid., 147.

${ }^{86}$ Ibid., 147.

${ }^{87}$ See Homer, The Iliad, translated by R. Lattimore (Chicago: University of Chicago Press, 1961), 13.601-627.

${ }^{88}$ See The Odyssey, 9.269-71 and 14.56-58.
} 
corresponding motif defining the obligation of the guest to the host ... not to overstay ones' welcome, and to have due regard for the substance of the host.... ${ }^{89}$

The little tradition's emphasis on the rights of hosts vis-à-vis guests is downplayed almost to the point of extinction in The Odyssey (though its ghostly trace remains in the epic's dénouement), which focuses rather on the host’s limitless generosity becoming a problem only in the case of the guest who wishes to move on. Reflecting the values of the courtly tradition, unconditional hospitality is thus valorised in The Odyssey even when charting its limits: as Telemachus is made to say, 'It is just as evil to push out a guest who is unwilling to leave as it is to retain one who longs to depart'. ${ }^{90}$ Indeed, the sentence that follows this one: 'One should entertain the guest who is present, and send on the one who wishes to go' apparently so offended the aristocratic tradition of unconditional hospitality that it was omitted from later versions. ${ }^{91}$ The little man, meanwhile, was less forgetful of the limits of hospitality because, in his poverty, he had to be mindful of the generous host 'beset by guests who abuse his hospitality to such an extent that they threaten his livelihood. By destroying his substance, they are in fact destroying him'. Thankfully, in this case the gods step in 'to punish this symbolic homicide with death'. Levy’s hypothesis is that this tale was commonly told by those little people who fail to write history as it provided a much needed counterpoint to the god-in-disguise (theoxenic) injunction to unconditional hospitality - a parallel (now spectral) story setting limits to the host's obligations by imposing divine sanctions on unreasonable guests: ${ }^{92}$

\footnotetext{
${ }^{89}$ Levy, 'The Odyssean Suitors', 149.

${ }^{90}$ The Odyssey, 15.68-74.

${ }^{91}$ Levy, 'The Odyssean Suitors', 150.

${ }^{92}$ Ibid., 150.
} 
We may imagine an audience of small farmers, shepherds, neatherds, and fisherfolk, listening with indignation to the recital of how the guests ate up the very essence of the host; each would hear in the tale an echo of his own inner conflict as, in his own home, he followed the dictates of hospitality on the one hand, but saw on the other his meager stores, the fruit of his hard labor, his very self, in fact, consumed. The hearers would wait with grim anticipation and rising emotion for the denouement, in which the wasters were destroyed by the gods, and thus put beyond the pale of human vengeance [which would set in train a potentially endless cycle of retaliation]. The utter destruction of the unjust guests would then be an ineradicable part of the story, expected by the hearers with considerable emotional affect, and not to be omitted no matter how the tale was otherwise modified. ${ }^{93}$

According to Bolchazy's distillation of cultural anthropology, fear of strangers is a common feature of very many, if not all, traditional communities and provides the kernel of what will later become hospitality. ${ }^{94}$ The stranger is feared for magico-religious reasons, for his potential to enchant the host or the host community with his powers. In Bolchazy's evolutionary schema of hospitality in prehistoric Greece and Rome (based on an exegesis of traces in the surviving texts of antiquity), as contact with strangers increases, this first stage of absolute xenophobia gives way to a stage of hospitality as ceremonial purification. Here, the necessary or unavoidable stranger (the trader, messenger or ambassador, for example) is disenchanted, or cleansed of their magico-religious capacity to harm the host. ${ }^{95}$ In the third stage, hospitality as a purification right gives way to hospitality as a disarming of the

\footnotetext{
93 Ibid., 150-1.

${ }^{94}$ Ladislaus J. Bolchazy, Hospitality in Antiquity: Livy’s concept of its humanizing force (Chicago: Ares, 1995).

${ }^{95}$ Interestingly, this stage of hospitality re-describes the assimilation of guests by hosts as initially a purification right, or right of passage, by which potentially dangerous strangers are incorporated 'into a group whose cohesion must be maintained' or initiated 'into the sacred covenant between a community and its gods' (Ibid., 6).
} 
stranger's bad will through kindness. For Bolchazy, this is the first stage of hospitality 'proper', but it arrives only as a result of the 'stranger danger' or xenophobia of the previous two stages. The fourth stage brings us to the Homeric era and to the theoxenic hospitality that we have already encountered above. Here, the host welcomes the stranger for he may be a god. This lingering magico-religious equation of the stranger with a god gives way, in the fifth stage, to the more abstract religious injunction that it is some god's will that the stranger be welcomed. Here we are in the territory of Zeus Xenios, the god of strangers of Greek antiquity which, according to Bolchazy, pre-figures the 'brotherhood of man' characteristic of later Stoic and Christian teachings. Bolchazy goes on to outline two further stages of the evolution of hospitality in antiquity: the quasi-contractual arrangements of 'guest-friendship' motivated by elite self-interest (to protection and representation in foreign lands) and, finally, the 'altruistic' hospitality which is seen by patrician Romans such as Livy as the distinguishing feature of civilization in contradistinction to barbarism.

The teleological and universalising aspects of Bolchazy’s stages of hospitality are counter to a genealogy of hospitality. Nevertheless, his core argument that hospitality in antiquity witnessed the gradual disenchantment of the stranger who was initially regarded with religious dread is well supported. That the lingering fear of the stranger was at this point the driver of hospitality is clearly visible in theoxeny which, as others than Bolchazy have shown, indisputably helped to establish the seemingly universal law of hospitality in antiquity. ${ }^{96}$ What Bolchazy’s account of the xenophobic aspect of pre-historic hospitality describes is the fearful and exposed host of the little people's hospitality narrative found in The Odyssey. What Bolchazy does not notice about his schema is that it is also a story of the

\footnotetext{
${ }^{96}$ See, for example, A.B. Cook, Zeus: A Study in Ancient Religion (Cambridge: Cambridge University Press Archive, 1940). As Herman shows, the institution of guest-friendship in the ancient world was by no means limited to the Greeks (Gabriel Herman, Ritualised Friendship and the Greek City (Cambridge: Cambridge University Press, 2002), 12).
} 
transformation of hospitality, in his final two stages (antiquity), from a communal practice to a largely elite activity. Hospitality in this period witnesses a radical disjuncture, beginning with xenophobia and ending with elite xenophilia; starting with fear of the stranger and finishing with fear of the mob. Though it becomes more cosmopolitan, it also becomes less popular. Indeed, by the high Roman era the xenophobic stages of hospitality are entirely hidden from view behind a cosmopolitan yet aristocratic veneer. Thus in On Duties Cicero is able to claim that 'it reflects splendidly on the republic that foreigners do not in our city go short of that [hospitable] kind of liberality'. ${ }^{97}$ Yet this claim is made alongside of, and deemed entirely compatible with, the observation that it is 'most seemly (or so it seems to me) for the homes of distinguished men to be open to distinguished guests'. Unconditional hospitality, while an irreducible remainder of the concept of hospitality as Derrida shows, as a practice traces its history back to a quasi-contractual ritual of guest-friendship, which was offered primarily by Homeric warrior-kings to fellow aristocrats in a conspicuous display of power, prestige and piety. ${ }^{98}$ This heroic hospitality (Levy's 'great tradition') is embedded not in the communal fear of strangers characteristic of Bolchazy’s earlier stages of protohospitality but in an aristocratic independence of communal obligation which was itself suppressed by the rise of the Greek polis. The polis saw the hero transformed into a citizen and thus made subject to community, but guest-friendship reflected an earlier autonomy:

For the poet [Homer], adherence to the code of guest-friendship was a supreme manifestation of the hero's free exercise of prowess. There was, in his world, neither overlord to demand feudal allegiance, nor communal group to claim social responsibility. The hero, the supreme pinnacle of a small social pyramid, was under

\footnotetext{
${ }^{97}$ Cicero, On Duties, ed. M.T. Griffin and E.M. Atkins (Cambridge: Cambridge University Press, 1991), II.64.

${ }^{98}$ Herman, Ritualised Friendship. For the Roman continuation of Greek guest-friendship, see Herman, Ritualised Friendship, 7 and Bolchazy, Hospitality in Antiquity, 52-3.
} 
no involuntary obligation to anyone; the guest-friendships he contracted were his own private affair. $^{99}$

Hospitality was offered with such largesse by Homeric heroes because it could be; but these heroes were also thereby able to preserve their elite power in a changing world of emerging city states through the mutual recognition that hospitality afforded. This is a strategy elites continue to utilise even to this day in a world of nation states and their ostentatiously hospitable summit meetings, state visits and exchange of diplomats. ${ }^{100}$ Guest-friendship ties thus acted as a repository of heroic values in the ancient world, enabling aristocrats in the first city states to 'find assistance in their political struggles and refuge in defeat':

Guest friendship served as a device for the promotion of the material and political interests of the elites engaged in it. ... [Indeed] at times the horizontal ties of solidarity which linked together the elites of separate communities were stronger than the vertical ties which bound them to their inferiors within their own communities. Outside the city, guest friendship functioned as a major device in the formation of the ruling circles of the great territorial empires. The Persian syngenics, Macedonian hetairoi and Hellenistic philoi were all composed of a narrow core of kin and a wide periphery of guest-friends drawn from an astonishing variety of localities. ${ }^{101}$

The elite nature of the unconditional hospitality or ritualised guest-friendship of antiquity is then its chief attribute. Herman shows that it was an 'overwhelmingly upper class institution'

\footnotetext{
${ }^{99}$ Herman, Ritualised Friendship, 2.

${ }^{100}$ Nicholas Onuf, 'Friendship and Hospitality: some conceptual preliminaries', Journal of International Political Theory 5, No. 1, 2009, 20.

${ }^{101}$ Herman, Ritualised Friendship, 8. See also Bolchazy, Hospitality in Antiquity, 43-4 and 99. Strikingly, Herman even attributes attacks on the Greek city by these empires as motivated 'by the desire to satisfy the personal interests of the guest-friends involved in these groups' (Herman, Ritualised Friendship, 8).
} 
identified almost exclusively with high-and-mighty characters such as heroes, kings, tyrants, satraps, noblemen and generals. ${ }^{102}$ Rough equality in wealth and power of the wealthy and powerful was the material condition of the unconditional hospitality characteristic of ritualised friendship. Even the terminology of guest-friendship reveals the centrality of this characteristic, since for the ancients friendship was by its nature a relationship between equals. ${ }^{103}$ Thus Herman concludes his authoritative study with the observation that the ancient institution of guest-friendship reveals more than anything else the persistence in the new world of the city-states of the cleavage between upper and lower classes: 'The main prerequisites for entering this sphere [of guest-friendship] were wealth, power and status; the main avenues of access, guest-friendship and marriage'. ${ }^{104}$ Guest-friendship with those outside of the city was not only a chief means by which the elite sought to distinguish themselves from their social inferiors within the city who would tame their power; it was also about winning that power back. And this elite strategy worked; after two centuries of relative escape from elite domination during the Classical age of the polis, by the Hellenistic era 'most cities were manipulated, if not effectively ruled, by leaders of factions supported by rulers abroad’. 105

It is partly because of this long-standing connection between aristocratic and unconditional hospitality that hospitality does not continue to have the baleful connotations for hosts that it had earlier; for the history of hospitality has largely been (over)written by elites welcoming fellow elites as friends, and not by the little people for whom hospitality meant the welcome of the stranger in all his (quite possibly malevolent) strangeness. Thus if deconstruction recovers the host haunted by the absent or wronged guest, by the hospitality he has withheld,

\footnotetext{
102 Ibid., 34.

103 Ibid., 37.

${ }^{104}$ Ibid., 162. Herman also demonstrates (p. 36) that guest-friendship was far superior to marriage in this regard. 105 Ibid., 164.
} 
genealogy recovers the host haunted by fear of the guest, by the hospitality he has offered that may prove his undoing. Derrida reminds us, speaking of the host, that because my 'at home' supposes a reception of the other in terms of appropriation, control, and mastery, in short 'according to different modalities of violence, there is a history of hospitality, an always possible perversion of the law of hospitality'. ${ }^{106}$ Yet there is another history of hospitality too, a history of (and of the fear of) appropriation, control and mastery not of the guest but of the host. This history has been neglected: in part because it is the fearful history of the little people who have always risked more in offering a welcome to the stranger but whose stories are marginal; in part because it has been overwritten by an elite hospitality which itself reflected a shift away from communal fear of strangers to elite fear of the mob. Derrida often points out that 'host' and 'hostility' share a common $\operatorname{root}^{107}$ - we know to beware Cyclops, paradigm of brutality towards guests. ${ }^{108}$ But the overlooked counter-warning, made by the little people who remain closer to that hospitality which is linked to xenophobia, is to watch out for Cortés too. Montezuma the host stands as a neglected remainder of unconditional hospitality — a ghostly presence that unsettles the takings of the guest. Hospitality is haunted indeed.

Hospitality calls for genealogy as much as it calls for deconstruction. Together, genealogy and deconstruction show that hospitality is inherently heterogeneous or impure, lacking the

\footnotetext{
${ }^{106}$ Derrida, On Cosmopolitanism, 17.

${ }^{107}$ The Latin hospes derives from hosti-pot-s, where pot means power, indicating 'guest-master', the supremacy of host over guest. Derrida talks up the significance of hospes as guest-master and its semantic closeness to the hostility of the hostis (Adieu, 57). Interestingly, however, the likely antecedent of the Greek xenos (stranger or guest in the case of the guest-friendship denoted by xenia) is found in the Linear B term ke-se-nu-wo, a term which denotes both host and guest, indicating a fundamental equality between the two (Bolchazy, Hospitality in Antiquity, 17-18). This is no doubt what we would expect in a prehistory of hospitality motivated originally by magico-religious awe of the guest.

${ }^{108}$ To Odysseus' plea for hospitality, the Cyclops replies that he will devour Odysseus last among his company: 'that shall be my gift of hospitality' (The Odyssey, 9.368-9). The Cyclops also announces that he 'cares nothing for Zeus', god of guests (9.276).
} 
stability required of an ethical foundation. The ethics of hospitality is always already a politics. 